\title{
The Socio-Economic and Cultural Condition of Fisherman in Coastal Area of Sialang Buah, Teluk Mengkudu, Deli Serdang Regency, North Sumatera
}

\author{
Mona Adria Wirda ${ }^{1}$, Nurmala Berutu ${ }^{1}$, Riki Rahmad ${ }^{1}$ \\ ${ }^{1}$ Department of Geography Education, Faculty of Social Sciences, State University of Medan \\ Jl. Willem Iskandar Psr V Medan Estate Medan, 20211 Indonesia \\ Email: monaadria@unimed.ac.id
}

\begin{abstract}
This research aims to identify of coastal communities chartered economic potency, explore the human resources potency of coastal communities, investigate the role of coastal communities chartered economic institution, and knowing both of the socio-economic condition and infrastructure support for the economic development of coastal areas in Serdang Bedagai Regency. This research was done in Pantai Sialang Buah Desa Teluk Mengkudu, Serdang Bedagai Regency. respondents took by random sampling method. Data analysis method of this research was applied descriptive analysis. The result of this research shows that communities economics potency at coastal area quite prospective. The social economic condition of communities at coastal area relatively still very lag, although the economic sector is very potential to be developed like fishery sector, cultivation of seagrass, beach tourism, field crop and breeding sector. The role of the government and the private sector in developing the potential of coastal communities is not sufficient, especially in the field of infrastructure.
\end{abstract}

Keywords: Coastal Area, Coastal Communities, Economic Potency

\section{Introduction}

Indonesia is one of the largest archipelagic countries in the world, with the island number reaching approximately 17,500 islands and is known as one of the country's largest biodiversity, including its wealth of coastal resources. As a consequence, Indonesia has a comparative advantage over other countries, especially the superiority of marine resources. As an archipelagic country, it is not surprising that approximately twothirds of the total territorial territory of this unitary state of the republic are water, with an area of approximately 5.8 million $\mathrm{km}^{2}$. In addition, Indonesia is also one of the countries that have the longest coastline in the world after Canada, which reaches approximately $81,000 \mathrm{~km}$. Of course with the wide waters, the length of the coastline and the number of such large islands, Indonesia naturally inherits a wealth of abundant marine resources. Therefore, approximately 60 percent of Indonesian people live and settle around coastal areas. So it is not surprising that most of the activities and daily activities are always related to the existence of coastal and marine resources in the vicinity. So here we will raise the issue and describe how the characteristics of the coastal areas, along with the social and economic conditions that exist in coastal areas.

According to Masyhudzulhak in the Proceeding Book of the State Administration Science Symposium for Indonesia (2011) coastal area is a meeting area between the influence of land and sea, landward until the area still influence the seepage seawater and sea breeze, and toward the sea until the area still exist the influence of fresh water that has a variety of resources. While Bengen in Apridar et al (2001) states that coastal areas are land areas and marine areas that meet on the coastline, where the terrestrial areas include flooded or unlogged areas influenced by marine processes such as tides, sea breeze, and seawater intrusion. While the sea area 
includes waters that are affected by natural processes of land such as sedimentation and freshwater flow into the sea and waters affected by human activities on land.

Based on the two definitions above, coastal areas cover two main areas, namely land and sea territories, which store a variety of resources, both on land and in the oceans. Coastal areas have a wide range of potentials, including primary food sources containing protein (especially animal protein derived from fish, shrimp, atc.); potential as mineral resources such as petroleum, and gas; and other potential such as tourism, residential and industrial development potentials. Therefore, the coastal area becomes a strategic area to be managed in order to fulfill the livelihood of the community, especially in relation to economic development that can guide the economy of the surrounding community, local government and other parties.

Coastal management involves many stakeholders. So that various interests meet in the name of coastal development. The potential possessed by the coastal area should be read as an opportunity to do development in various aspects of life for the welfare of people's lives, one of which is through the development of coastal areas into tourism objects. Today, the field of tourism is a potential field in the development of a country, because tourism is considered to bring a positive impact as a motor of people's economic activity. Areas with tourism potential can revive the economic activities of surrounding communities with the incidence of small to medium-sized enterprises, reduce unemployment, increase public revenues, and increase local revenues (PAD) which will be re-used by the government to carry out development in the region and achieve prosperity. Gamal Suwantoro (1994) argues that many countries in the world consider tourism an important and integral aspect of the country's development strategy, as every tourism literature provides reviews that the tourism sector provides economic benefits to the country concerned. These benefits are usually derived from foreign exchange earnings, government revenues, regional development stimuli, and the creation of labor and income generation.

The case study is located in Pantai Sialang Buah Teluk Mengkudu Village, Serdang Bedagai Regency which is on coastal area. Coastal areas are rich in natural resources that are widely used by people who live on the coast. Aside from being a place for food, people also take advantage of coastal areas as transportation and ports, industrial estates, agribusiness and agroindustry, tourism, and residence areas. Sialang Buah Beach is a beach located in Sialang Buah Village which in the western part of this coast there is Kelang Beach and in the east part of this coast there is Pantai Mutiara Indah. This beach is one of the popular coastal areas which quite attractive as a tourist attraction. People who live on this beach mostly livelihood as a fisherman. On this beach, there is a a Fish Auction Place (TPI) where fishermen can directly sell the catch to the TPI. There is also a cultivation area (pond) on this beach.

\section{Methods}

a. The research method is one of the clear structural steps in responding to the clear research context. in the application of this research method, there are important points covering research design, location and subject of research, data collection techniques and data analysis techniques. According to Department P and K (1995) that "Method" is an orderly way of thinking to achieve intent in science, and a systematic way of working to facilitate the execution of any activity. In this research used qualitative research approach. An expert says that research methods undertaken in natural situations and data collected are generally qualitative in nature. A qualitative approach is more based on the phenomenological philosophy that prioritizes appreciation (verstehen). Qualitative methods try to understand and interpret the meaning of an interaction event of human behavior in certain situations from the perspective of the researcher himself (Husnaini Usman, 2004). The type of research in this study is basic research. Jujun S. Suriasumantri (1985) states that basic or pure research is research that aims to discover new knowledge that has not previously been known (Sugiyono 2007). This research was conducted at Pantai Sialang Buah located in Teluk Mengkudu Serdang Berdagai Regency. This research uses primary data. Primary data is data that obtained and collected directly from indigenous sources. In this case, primary data collected from the village government and the whole community that can provide proper data that needed by researchers. 


\section{Result and Discussion}

\section{The general state of the village}

Teluk Mengkudu Village is one of the island villages located at the eastern end of Serdang Bedagai Regency with a land area about 65 ha. The number of Teluk Mengkudu villagers in 2007 was 1,089 (51.52\% male and $48.48 \%$ female), with productive workforce age (16 - 50 years) recorded $58.31 \%$ and unproductive ( $<15$ years) or less productive ( $>51$ years) $41.69 \%$. Most of the population (90\%) are Muslim, the rest are Protestants.

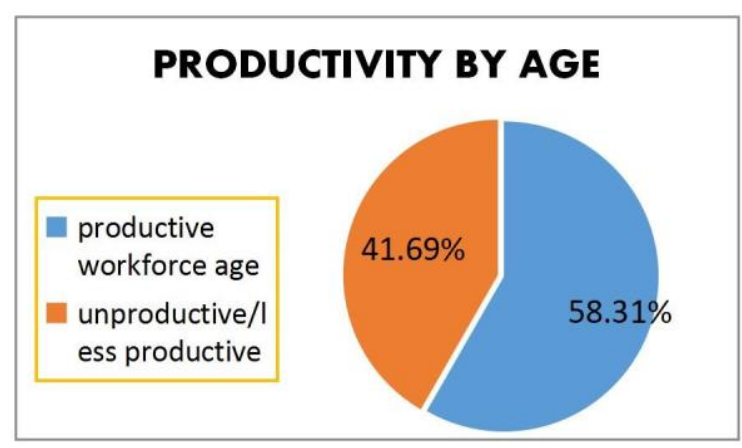

Public education level, in general, is still low, because most of the population is only elementary school then followed by junior high school. This is likely due to the lack of educational facilities and infrastructure available (only 1 SD Inpres and 1 open SMP receiving new students starting in 1995). When going to higher education, junior high school graduates should go to the subdistrict capital (Perbaungan) and this will greatly burden the parents in terms of transportation costs. Based on the data from Teluk Mengkudu Village Profile in 2007, it was found that out of 303 people with livelihoods, $78.55 \%$ were fishermen, followed by traders or tibotibo $(11.55 \%)$, farmers $(3.30 \%)$, entrepreneurs $(3.30 \%)$, and workers or laborers $(2.31 \%)$, the rest $(0.99 \%)$ are teachers (PNS).

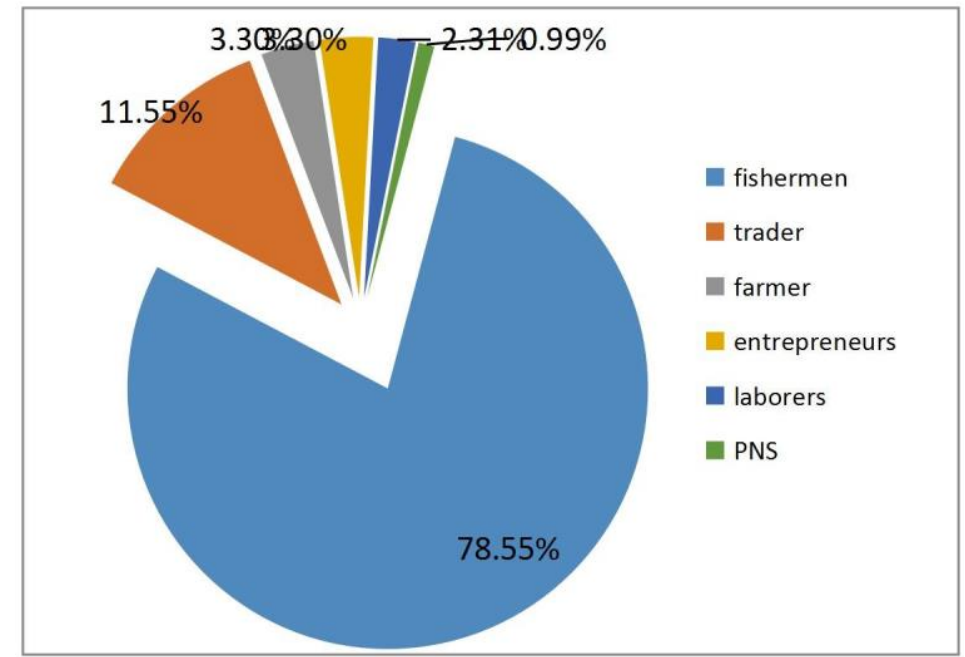

\section{Socio-Economic Factors}

Based on direct observation and interviews with the people who live in coastal area of Sialang Buah, the total scores obtained for socioeconomic factors that amounted to 200. Total Value Scoring (TNS) This shows that socio-economic factors affect the destruction of mangrove forest area. So it can be concluded that the socioeconomic factors of coastal communities of Sialang Buah are the most factor that influence level of mangrove damage in the area. Based on the results of interviews conducted at Sialang Buah Village Beach it is known that the majority of the people who live there depend on their economy on marine and coastal resources either as fishermen or fisherman workers cultivators, fish catchers, traders, superintendent of beach tourism and as a transportation provider of the catch of fisherman. 
Nikijuluw (2001) states that coastal communities are defined as groups of people living in coastal areas and their economic resources depend directly on the utilization of marine and coastal resources, consisting of fisherman owners, fishermen workers, fish farmers and other marine organisms, fish traders, fish processors, the supplier of fishery production facilities. Business location and settlement which is too close to mangrove ecosystem even directly utilize mangrove land become one of the triggers of mangrove forest ecosystem destruction caused by activity of economy of society at Pantai Sialang Buah which will give negative impact to environment directly or indirectly and biggest impact and damage of mangrove ecosystem will have an impact on the economic and social potential of the region will be reduced and may disappear, and the majority of people who are livelihoods as fishermen will find it increasingly difficult to find fish.

Utina (2008) stated that it is necessary to comprehend society comprehensively from the various functions of this mangrove ecosystem so that there are conservation and maintenance efforts. The Perception of Coastal Communities and Visitors to Tourism $88 \%$ said that they know mangroves and only $12 \%$ are not familiar with or know the mangrove forests, most people know the function of mangrove is as a protector of the beach from the dangers of erosion and the place of the life of various types of fish. Harahab (2010) stated that mangrove forest vegetation with various forms of roots is able to withstand the abrasion, flood, tsunami and other ecological functions such as feeding ground, for the animals and as a nursery ground, spawning ground and spawning ground. As many as $65 \%$ of community respondents said it is necessary to rehabilitate mangroves and as many as $70 \%$ of the respondents also said that mangrove rehabilitation should be done on the beach.

Mangkay et al. (2012) stated that to realize its utilization in order to be sustainable, mangrove forest needs to be maintained, mangrove forest management is an effort to protect mangrove forest into conservation forest area and reforestation of mangrove forest such as reforestation to restore aesthetic value and ecological function of area mangrove forests that have been felled and transferred to other activities. As many as $91 \%$ of tourists respondents said Ada and 9\% say no. Pramudyanto (2014) states the negative impacts of coastal tourism activities on the environment ie the decline of coastal and marine environmental quality as well as the sustainability of natural resources, ie pollution and environmental damage and excessive use of coastal and marine resources. In relation thereto, the efforts to control pollution and environmental damage that may arise should be part of the policy and action steps of environmental management in each sector of development activities.

From the results of research conducted in Teluk Mengkudu village it is found that social relationships of society are still very strong in their social life so very closely. This occurs when one of the citizens experiencing a disaster such as death, then without the command of the community will come voluntarily to provide assistance both in the form of material and in other forms. The social organizations in this village are the organizations of peace and blessings, the youth associations, the mothers of the Tahlim assemblies, the gotongroyong (mutual cooporate) at weddings, and the school committees. The social organization of this pillar of grief has long been established for generations and to this day has survived and gone well. This organization is officially regulated by the village government in which each member is required to pay Rp. 3,000 and brought one liter of rice when one member died. All of these married villagers automatically become members of this social organization of grief, while other social organizations, not all villagers are members. In the field of education, there is a school committee organization that conducts activities in the form of fundraising for the physical construction of schools.

In this village, there is no company-based business, except for several household-based businesses such as food stalls. In this village there is a traditional fishery business which is managed with low economic scale and business management which is family character. there is no one organization of work because usually the process of fishing is done alone, while the fishermen on catching soma pajeko and seine pukat using labor, there is a regular organization of work. Along the coast of the village is an active fishing area by fishermen. The fishing season does not fly all the time depending on wind, weather, waves, and ocean currents. This condition can not be separated from the influence of tropical climate with dry season (June September) and rainy season (December - March), with transition season April - May and October November.

From the research results obtained fisherman income comes from fishery business and activities outside the fishery. Revenue from outside the fishery business is also divided into two, namely income from agriculture and others, but most of the fisherman's income is sourced from capture fishery business. The fish catch and/or 
their crops such as bananas, yams, coconuts, and others to the Likupang market. Income or income per month from the sector of fisheries received by fishermen and all family members who work is always changing. This change can sometimes lead to changes in fish behavior (migration and spawning) as well as the periodicity of fishing. When the (hot) dry season arrives where the wind is blowing from the south, it will affect the fishing activities along the southern coast, especially the fishermen with fishing gear and beach trawlers; so when the rainy season arrives where the wind blows from west to north, it will affect the activities of people along the northern coast. Meanwhile, the expenditure of fishermen in this village is relatively varied. Expenditure of each family head (KK) per month on average Rp. 790,000, with details of expenditures on average Rp. 225,000; clothing average Rp. 500.000, housing Rp. 5,000, education Rp.

20.000, health Rp. 20,000, and expenditure of Rp. 20,000.

The average number of family members in each fishing family in this village is 4 people, consisting of father, mother, and two children. the Education level of Teluk Mengkudu villagers in general $(63.3 \%)$ is primary school. This is due to environmental factors in which children tend to go to the sea rather than to school, in addition to the lack of motivation or encouragement of parents for their children to go to school again. But there are also some respondents whose children can finish high school, because their parents have set aside some money for the educational needs of children at each time get the catch of fish that abundant with adequate income. Based on the results of interviews with the fishing community, the types of diseases that are commonly suffered in general are allergies, itching, diarrhea and diarrhea, fever, influenza, and cough. Treatment is done only by buying medicine in a stall, and if the disease is getting worse, usually directly seek treatment at the health center or hospital. Unavailability of health facilities and health counseling from the government cause people in this location do not pay much attention to their health problems. From the results of observations and interviews conducted, obtained information that those who work as fishermen in general just to meet their primary needs is to find food. The talents and skills gained from parents as fishermen are naturally transmitted to children since the location of their settlements are close to the coastal areas. In addition to working as fishermen, fishermen also have side jobs, such as farmers, laborers, traders, and artisans who do not make a fishing effort in the sea because of weather that does not allow to go fishing at sea.

\section{Conclusions}

The population of Teluk Mengkudu village is 1,089 people, $90 \%$ are Islamic, formalized primary school, and $78.55 \%$ are mostly fishermen, using a variety of fishing gear, where 51\% of fishermen earn Rp. 610,000 $\mathrm{Rp} 800,000$ per month, which has an impact on the low level of welfare of fishermen families. Social and economic organizations can be useful in improving the living standards and quality of life of people in this village. Need to do further research on socio-economic coastal communities so it can be known the benefits of coastal ecosystems to the social and economic community. The role of government in maintaining the environmental condition of Sialang Buah Beach from the public in particular and also need awareness of every visitor to the tour to help preserve the sustainability and sustainability of the tourist attractions.

\section{References}

Dahuri, R., J. Rais, S.P. Ginting, S.P dan M.J. Sitepu. (2004). Pengelolaan sumberdaya wilayah pesisir dan lautan secara terpadu. PT. Pradnya Paramita, Jakarta. Dien, Ch., 2004. Analisis sosial ekonomi masyarakat nelayan di pantai utara dan selatan Kabupaten Bolaang Mongondow. Tesis, Pascasarjana Universitas Sam Ratulangi, Manado (tidak dipublikasikan).

Fahrudin, A. (2004). Penelitian sosial ekonomi dalam perencanaan dan pengelolaan wilayah pesisir. Bapeda Provinsi Sulawesi Utara, Manado.

Lisk, F. (1981). Strategi pembangunan konvensional dan pemenuhan kebutuhan dasar dalam pembangunan ekonomi dan pemerataan. LP3S, Jakarta.

Mangkay, S., Harahab, N., Polii, B dan Soemarno. (2012). Analisis Strategi Pengelolaan Hutan Mangrove Berkelanjutan Di Kecamatan Tatapaan, Minahasa Selatan, Indonesia. Universitas Brawijaya. J-PAL. 3 (1) : 8-18 
Mantjoro, E. (1988). Social and economic organization of rural Japanese fishing community: A Case of Nomaike. Master program, Department of Fisheries, Tokyo University, Japan (unpublished).

Mantjoro, E. (1997). Sejarah penduduk dan lingkungan hidup Desa Talise. Konsuttan sosio-ekonomi. Proyek Pengelolaan Sumberdaya Wilayah Pesisir, Universitas Sam Ratulangi, Manado.

Masyuri, I. (2001). Pemberdayaan masyarakat nelayan. Media Presindo, Jogjakarta.

Mawardi, I. (2008). Pengembangan Ekowisata sebagai Strategi Pelestarian Hutan Mangrove (Studi Kasus Hutan Mangrove di Pantai Utara Kabupaten Idramayu). Badan Pengkajian dan Penerapan Teknologi. Jurnal Teknologi Lingkungan. 7 (3) : 234-242

Nikijuluw, P. V. H. (2001). Populasi dan Sosial Ekonomi Masyarakat Pesisir serta Strategi Pemberdayaan Mereka dalam Konteks Pengelolaan Sumberdaya Pesisir Secara Terpadu. Pusat Kajian Sumberdaya Pesisir dan Lautan. Institute Pertanian Bogor. Bogor.

Pramudyanto, B. (2014). Pengendalian Pencemaran dan Kerusakan di Wilayah Pesisir. Kementerian Lingkungan Hidup dan Kehutanan. Banten. Vol 1 (4). 21-40.

Sebenan, R.D. (2007). Strategi pemberdayaan rumah tangga nelayan di Desa Gangga II kecamatan Likupang Barat Kabupaten Minahasa Utara. Fakultas Perikanan dan llmu Kelautan, Universitas Sam Ratulangi, Manado.

Salim, E. (1977). Perencanaan pembangunan dan pemerataan pendapatan. Inti Indayu Press, Jakarta.

Tulungen, J. (2002). Program pengelolaan sumberdaya wilayah pesisir terpadu dan berbasis masyarakat: Telaah kasus di Kabupaten Minahasa Sulawesi Utara, Manado.

Utina R. (2008). Pendidikan Lingkungan Hidup dan Konservasi Sumberdaya Alam Pesisir. UNG-Press. Gorontalo. 